\title{
Effect of Fluoxetine Hydrochloride on Routine Metabolism of Lambari (Deuterodon iguape, Eigenmann, 1907) and Phantom Shrimp (Palaemon pandaliformis, Stimpson, 1871)
}

\author{
Karina Fernandes Oliveira Rezende \\ https://orcid.org/0000-0002-7284-4443
}

Genésio Lopes Mercês de Almeida ${ }^{1}$

https://orcid.org/0000-0002-7451-5635

Marcelo Barbosa Henriques ${ }^{2}$

https://orcid.org/0000-0003-1419-9121

Edison Barbieri ${ }^{1 *}$

https://orcid.org/0000-0002-7423-3726

${ }^{1}$ Government of the State of São Paulo, APTA, Fisheries Institute, Cananeia, São Paulo, Brazil; ${ }^{2}$ Government of the State of São Paulo, APTA, Fisheries Institute, Santos, São Paulo, Brazil.

Editor-in-Chief: Paulo Vitor Farago

Associate Editor: Marcelo Ricardo Vicari

Received: 2020.04.30; Accepted: 2020.11.13.

*Correspondence: edisonbarbieri@yahoo.com.br (E.B.).

\section{HIGHLIGHTS}

- Fluoxetine increases the metabolic rate and excretion of ammonia in both species.

- O:N ratio in fish showed higher values in the highest concentrations of fluoxetine.

- The LC50 - 96 hour values of Palaemon pandaliformis represented greater toxicity.

- Both species are a good biological model for fluoxetine exposure studies.

Abstract: Fluoxetine is an emerging pollutant that acts as a selective serotonin reuptake inhibitor (SSRI) and being a hydrolytic molecule that is photolytically stable and accumulaties in biological tissues, its disposal in the aquatic environment can interfere with the physiology of fish and shrimp. Thus, the objective of this study was to analyze the effects of fluoxetine on routine metabolism (metabolic rate, specific ammonia excretion and O:N ratio) of Deuterodon iguape and Palaemon pandaliformis. For this, five groups of each species, were exposed to different concentrations of fluoxetine for 24 hours ( $D$. iguape) and 2 hours ( $P$. pandaliformis). The results demonstrated that in $D$. iguape exposure to fluoxetine significantly increased both the metabolic rate by $75 \%, 85 \%, 55 \%$ and $50 \%$ for concentrations of $0.05 ; 0.1 ; 0.5$ and $1.0 \mathrm{mgL}^{-1}$, respectively, and the specific ammonia excretion by $40 \%, 48 \%$ and $20 \%$ for concentrations of $0.05 ; 0.1$ and $0.5 \mathrm{mgL}^{-1}$, respectively, when compared with their control. The O:N ratio was statistically greater in concentrations of 0.5 and $1.0 \mathrm{mgL}^{-1}$. Concerning $P$. pandaliformis, exposure to fluoxetine increased metabolic rate at concentrations 30.0 and 
$60.0 \mathrm{\mu gL}^{-1}$, and also increased specific ammonia excretion at concentrations $10.0,30.0$ and $60.0 \mu \mathrm{gL}^{-1}$, when compared with the control group. It was concluded that exposure to fluoxetine increases the routine metabolism of both species and that at the concentration $1.0 \mathrm{mgL}^{-1}$, Deuterodon iguape required different energy substrates.

Keywords: metabolic rate; ammonia excretion; O:N ratio; antidepressant; drug.

\section{INTRODUCTION}

Fluoxetine is an emerging pollutant that is a selective serotonin reuptake inhibitor (SSRI) and its molecular formula is $\mathrm{C}_{17} \mathrm{H}_{18} \mathrm{~F}_{3} \mathrm{NO}$ (molecular weight: $345.79 \mathrm{~g} \mathrm{~mol}^{-1}$ ). This chemical, after consumption, is metabolized in the liver to norfluoxetine $\left(\mathrm{C}_{16} \mathrm{H}_{16} \mathrm{~F}_{3} \mathrm{NO}\right.$; molecular weight: $\left.295.305 \mathrm{~g} \mathrm{~mol}^{-1}\right)$, which also acts as an SSRI with a fluoxetine-like potency $[1,2]$.

The SSRIs target central nervous system neurons by inhibiting the serotonin transporter (SERT) which is responsible for the reuptake of serotonin (5-hydroxytryptamine, 5-HT) by the presynaptic neuron. Consequently, it increases the amount of this neurotransmitter available at synapse, enhancing its effect [35]. The 5-HT plays important roles such as wakefulness, aggression, appetite [5] and modulation of motor production [6] and is considered one of the most important neurotransmitters of the animal kingdom [7].Thus, SSRIs are drugs prescribed for the treatment of diseases such as depression, anxiety, panic disorder and obsessive-compulsive disorder $[1,8]$. Among these drugs, fluoxetine is one of the most prescribed in the world [9].

It is noteworthy that, according to the Organization for Economic Cooperation and Development (OECD), the consumption of antidepressants has increased over $60 \%$ in the last decade [10]. Therefore, it is estimated that depressive disorders affect 350 million people worldwide, of which $4.86 \%$ are Brazilians [11], and this number will tend to increase in the coming years, since the World Health Organization predicts that depression will be the second largest public health disability in 2020 [12].

Fluoxetine is excreted from the human body primarily through the urinary system, where approximately $10 \%$ is eliminated as the parent compound (fluoxetine) and the remainder is eliminated as norfluoxetine $[1,13]$. Both compounds enter water treatment facilities through both human waste and the disposal of this drug, unused, in the sink or toilet [14]. Kwon and Armbrust [15] warn that this compound is hydrolytic and photolytically stable in water causing a relatively long half-life and is not eliminated after the effluent treatment. As a result, environmental concentrations of this drug are often detected, ranging from 0.012 to $1 \mathrm{\mu g} \mathrm{L}^{-1}$ $[16,17]$, which raises concerns about its potential effects on biota [18].

In addition, it is suggested that entrapment of fluoxetine/ norfluoxetine in cell lysosomes may cause retention in biological tissues [19]. These characteristics increase the probability of the bioaccumulation of these substances in organism target tissues [20,21] like the brain [22,23], muscle and liver [22,24].

Thus, improperly discarding this drug leads to concerns about the health of organisms and, consequently, with the ecosystem. Aquatic vertebrates and invertebrates become susceptible to the action of fluoxetine and norfluoxetine because some of their physiological processes are also regulated by $5-\mathrm{HT}$ [25]. Studies show that fluoxetine exerts anxiolytic effects on fish and may interfere with neuroendocrine stress axis activity [26,27] affecting various levels of neuropeptides such as neuropeptide $Y$, oxytocin and arginine vasopressin [28]. Henry and Black [29] alert that substances that act on the neuroendocrine system can negatively affect organisms, even at low environmental concentrations. Interference in neuroendocrine stress axis activity influences behavior (aggression, appetite) [5], endocrine and reproductive parameters $[30,31]$, and compromises survival [32] since the stress response helps individuals cope with adverse conditions [33,34].

In invertebrates, studies show that serotonin plays an important role in physiology and behavior, such as aggression [35], spawning induction [36], swimming [37] and feeding [2]. However, effects of exposure to fluoxetine on aquatic organisms are not yet fully understood [5,38]. Fluoxetine was found between 0.14 and $1.02 \mathrm{~g} \mathrm{~kg}^{-1}$, in tissues of fish species: Ameiurus nebulosus, Dorosoma cepedianum and Morone americana [39].

D. iguape, known as lambari, belongs to the order Characiforme. It is commonly found in small rivers and streams of tropical and subtropical regions and is native to the Atlantic Forest watershed [40]. This species is widely used in the fishing market both for human consumption and for use as live bait in recreational fisheries [41,42]; mainly of tucunaré (Cichla spp.) and south american silver croaker (Plagioscion squamosissimus) [41,43], which helps to reduce juvenile shrimp fishing [44]. Palaemon pandaliformis (known as phantom shrimp) is a small crustacean decapod. Having a great osmoregulatory capacity [45], this species 
is found in freshwater and estuarine environments from the southern coast of Brazil to Guatemala [46]. Ferreira and coauthors [47] highlights the ecological importance of these organisms in the cycling of organic nutrients, in addition to being part of the diet of fish and birds.

Routine metabolism is a technique that assesses the daily energy expenditure of fish (non-fed) in their routine activity that includes spontaneous swimming movements [48]. Thus, many current studies on aquatic animals use this assessment to measure the toxicity of a chemical [49], such as graphene oxide with trace elements [50], multiwalled carbon nanotubes and carbofuran [51], titanium dioxide nanoparticles [52], nickel [53], perfluorooctane sulfonate [54].

In this context, it was hypothesized that exposure of $D$. iguape and $P$. pandaliformis to fluoxetine hydrochloride would interfere with the neuroendocrine stress axis, causing changes in its metabolism, revealed by the increase in metabolic rate and specific ammonia excretion. In addition, it is believed that to maintain homeostasis, fish and shrimp will use different energy sources revealed by the O:N ratio. The objective of this study was to analyze the sublethal effects of different concentrations of fluoxetine hydrochloride on routine metabolism (metabolic rate, specific ammonia excretion and $\mathrm{O}: \mathrm{N}$ ratio) of Deuterodon iguape and Palaemon pandaliformis.

\section{MATERIAL AND METHODS}

This study was carried out according to the ethical principles for animal experimentation adopted by the Brazilian School of Animal Experimentation (COBEA) and received authorization (no. 06/2016) from the Ethics Committee in Animal Experimentation of the Fisheries Institute, São Paulo, Brazil.

Deuterodon iguape and Palaemon pandaliformis were purchased from a fish farm located on the coast of São Paulo and were kept at the Fisheries Institute (Cananéia Laboratory) Secretary of Agriculture of the São Paulo State, on the southeastern coast of Brazil. Each species remained in different 500L tanks for one week for their acclimatization with constant aeration and daily water change. The freshwater used for maintenance was filtered through three $2 \mu \mathrm{m}$ filters, two $1 \mu \mathrm{m}$ filters and one $0.5 \mu \mathrm{m}$ filter arranged sequentially.

The temperature of the tanks was constantly monitored with a mercury thermometer (accuracy of $0.5^{\circ} \mathrm{C}$ ), and was maintained at $22.75^{\circ} \mathrm{C} \pm 0.27^{\circ} \mathrm{C}$ (mean \pm standard deviation). The animals were fed commercial feed once a day during this period. Feeding was suspended 24 hours before the test. No animals were used more than once.

Fluoxetine hydrochloride (N-methyl-3-phenyl-3- [4- (trifluoromethyl) phenoxy] propane-1-amine $\mathrm{C}_{17} \mathrm{H}_{18} \mathrm{~F}_{3} \mathrm{NO}$ ) was used as a reagent. The choice of this drug was based on its predominance (approximately $68.8 \%$ ) among antidepressant prescriptions [55]. It is also noteworthy that Brazil has little research focused on the toxicity of medicines in the aquatic environment. Using an analytical balance with a resolution of $0.0001 \mathrm{~g}$, the reagent was diluted in a stock solution of $100 \mathrm{mg} / 100 \mathrm{~mL}$ of distilled water immediately prior to use to prevent substance degradation. For each species, four different concentrations were tested, as well as a control group (water without the drug). Fluoxetine hydrochloride was introduced at a determined nominal concentration into the aquariums using a $0.1 \mathrm{ml}$ precision pipette (accuracy $\pm 0.8 \%$; precision $0.4 \%$ ).

A total of 25 lambaris, with a mass of $9.87 \mathrm{~g} \pm 1.66 \mathrm{~g}$ (mean \pm standard deviation), were randomly divided into 5 glass aquariums, with a capacity of 6 liters (5 lambaris in each aquarium), containing different concentrations of fluoxetine hydrochloride $\left(0.0,0.01,0.1,0.5\right.$ and $\left.1 \mathrm{mg} \mathrm{L}^{-1}\right)$. In addition, 25 shrimps were also divided into 5 glass aquariums, with the same capacity ( 5 shrimps in each aquarium), with different concentrations of fluoxetine hydrochloride $\left(0.0 ; 5.0 ; 10.0 ; 30.0\right.$ and $\left.60.0 \mathrm{mg} \mathrm{L}^{-1}\right)$. The animals were kept in this condition for a period of 24 hours ( $D$. iguape) and 2 hours ( $P$. pandaliformis), at a controlled temperature $\left(22.75 \pm 0.27^{\circ} \mathrm{C}\right)$ and without feeding.

After exposure, the fish and shrimps were acclimated, separately, in cylindrical glass respirometers for 1 hour with continuous water circulation to alleviate the stress caused by handling. Then, the water supply was suspended, and the respirometer was closed so that the organisms could consume the oxygen in the known water volume for a period of one hour. The respirometers were protected by a barrier to isolate the animals from possible movement in the laboratory.

A water sample was then taken from each respirometer. The difference between oxygen and ammonia concentrations determined at the beginning and end of confinement was used to calculate the metabolic rate $\left(\mathrm{mLO}_{2} \mathrm{~g}^{-1} \mathrm{~h}^{-1}\right)$ and specific ammonia excretion $\left(\mathrm{mg} \mathrm{L}^{-1}\right)$ during the period, considering the volume of the respirometer, the wet weight of the animal and the confinement time. To minimize the effects of low oxygen concentration and metabolite accumulation on metabolism, the duration of the experiment was regulated so that the final oxygen concentration was greater than $70 \%$ of its initial concentration. Dissolved oxygen was 
determined by the Winkler method and ammonia excretion by the Nessler method (Standard Methods for the Examination of Water and Wastewater).

The atomic oxygen consumption rate (OCR) and ammonia excretion rate (AER) (O:N ratio) was calculated using the following equation $\mathrm{O}: \mathrm{N}$ ratio $=(17 \times \mathrm{OCR}) /(16 \times \mathrm{AER})[56]$.

The data were evaluated according to means and standard deviations obtained by one-way ANOVA followed by Tukey's post-test after verification of normal distributions (Kolmogorov-Smirnov test) and homoscedasticity (Levene test). Differences were considered significant when $p<0.05$.

\section{RESULTS}

In Deuterodon iguape, the metabolic rate increased significantly in all groups exposed to different fluoxetine concentrations when compared to the control group (ANOVA; $p<0.05$ ) (Figure 1). The increase of the groups exposed to fluoxetine was by $75 \%, 85 \%, 55 \%$ and $50 \%$ for concentrations of $0.05 ; 0.1 ; 0.5$ and $1.0 \mathrm{mg} \mathrm{L}^{-1}$, respectively. The data indicate a tendency to decrease the metabolic rate with higher concentrations $\left(0.5\right.$ and $\left.1.0 \mathrm{mg} \mathrm{L}^{-1}\right)$ when compared to lower concentrations $\left(0.05\right.$ and $\left.0.1 \mathrm{mg} \mathrm{L}^{-1}\right)$.

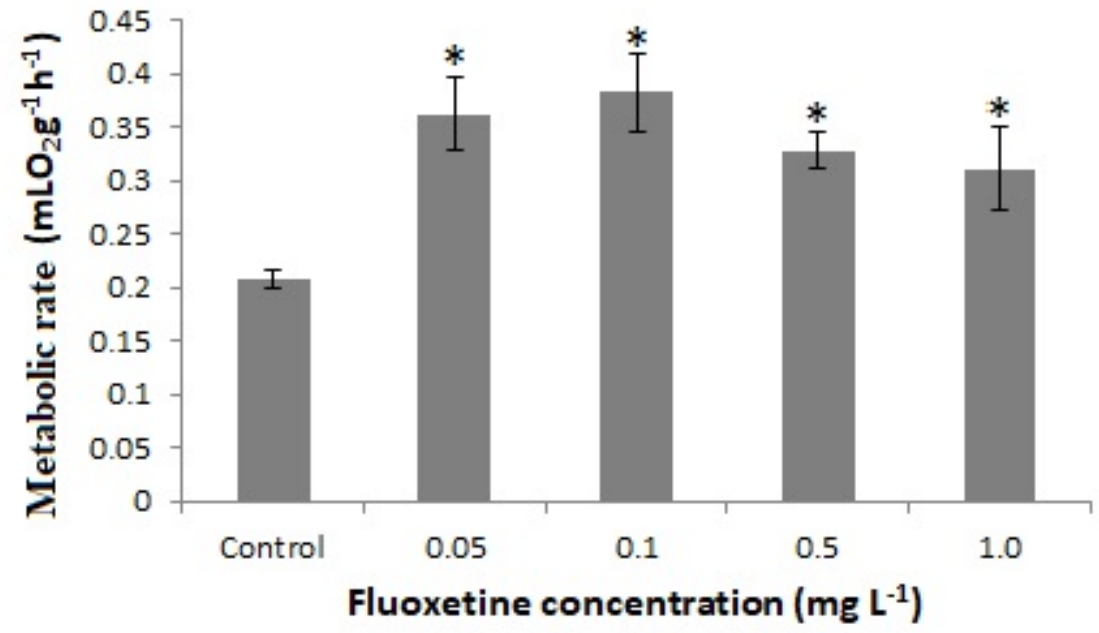

Figure 1. Mean of metabolic rate $\left(\mathrm{mLO}_{2} \mathrm{~g}^{-1} \mathrm{~h}^{-1}\right)$ relative to different fluoxetine concentrations $\left(\mathrm{mgL}^{-1}\right)$ of Deuterodon iguape. The bars are the respective standard deviations. *Indicates statistical difference compared to the control group.

A statistically significant increase of the specific ammonia excretion in the exposed groups were observed at concentrations of $0.05,0.1$ and $0.5 \mathrm{mg} \mathrm{L}^{-1}$ fluoxetine when compared to the control group (ANOVA; $p<0.05$ ), in Deuterodon iguape. However, the group exposed to $1.0 \mathrm{mg} \mathrm{L}^{-1}$ fluoxetine showed no statistical difference (Figure 2). The increases were by $40 \%, 48 \%$ and $20 \%$ for fluoxetine concentrations of $0.05 ; 0.1$ and $0.5 \mathrm{mg} \mathrm{L}^{-1}$, respectively, alerting to the same trend of metabolic rate; where, the increase is greater at lower concentrations $\left(0.05\right.$ and $\left.0.1 \mathrm{mg} \mathrm{L}^{-1}\right)$ than at higher concentrations $\left(0.5\right.$ and $\left.1.0 \mathrm{mg} \mathrm{L}^{-1}\right)$. 


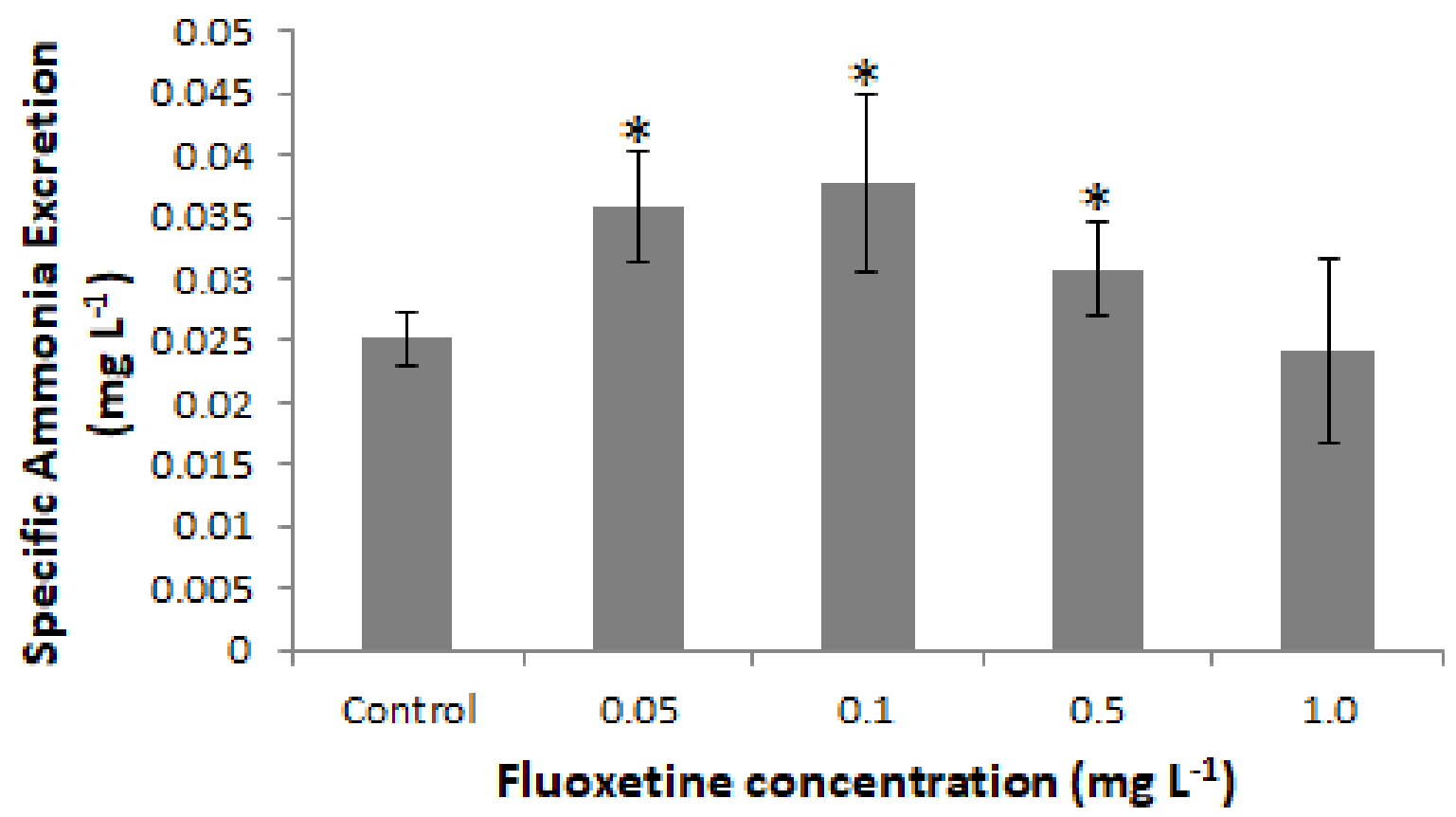

Figure 2. Mean of specific ammonia excretion $\left(\mathrm{mgL}^{-1}\right)$ relative to different fluoxetine concentrations $\left(\mathrm{mgL}^{-1}\right)$ of Deuterodon iguape. The bars are the respective standard deviations. *Indicates statistical difference compared to the control group.

By analyzing the atomic oxygen consumption ratio (OCR) to ammonia excretion ratio (AER) (O:N ratio) in Deuterodon iguape, it was shown that no statistical differences were found in the exposed groups with the lowest concentrations of fluoxetine $\left(0.05\right.$ and $\left.0.1 \mathrm{mg} \mathrm{L}^{-1}\right)$ when compared to the control group. On the other hand, the groups exposed to the highest fluoxetine concentrations $\left(0.5\right.$ and $\left.1.0 \mathrm{mg} \mathrm{L}^{-1}\right)$ had a statistical difference when compared to the control (ANOVA; $p<0.05$ ) (Figure 3).

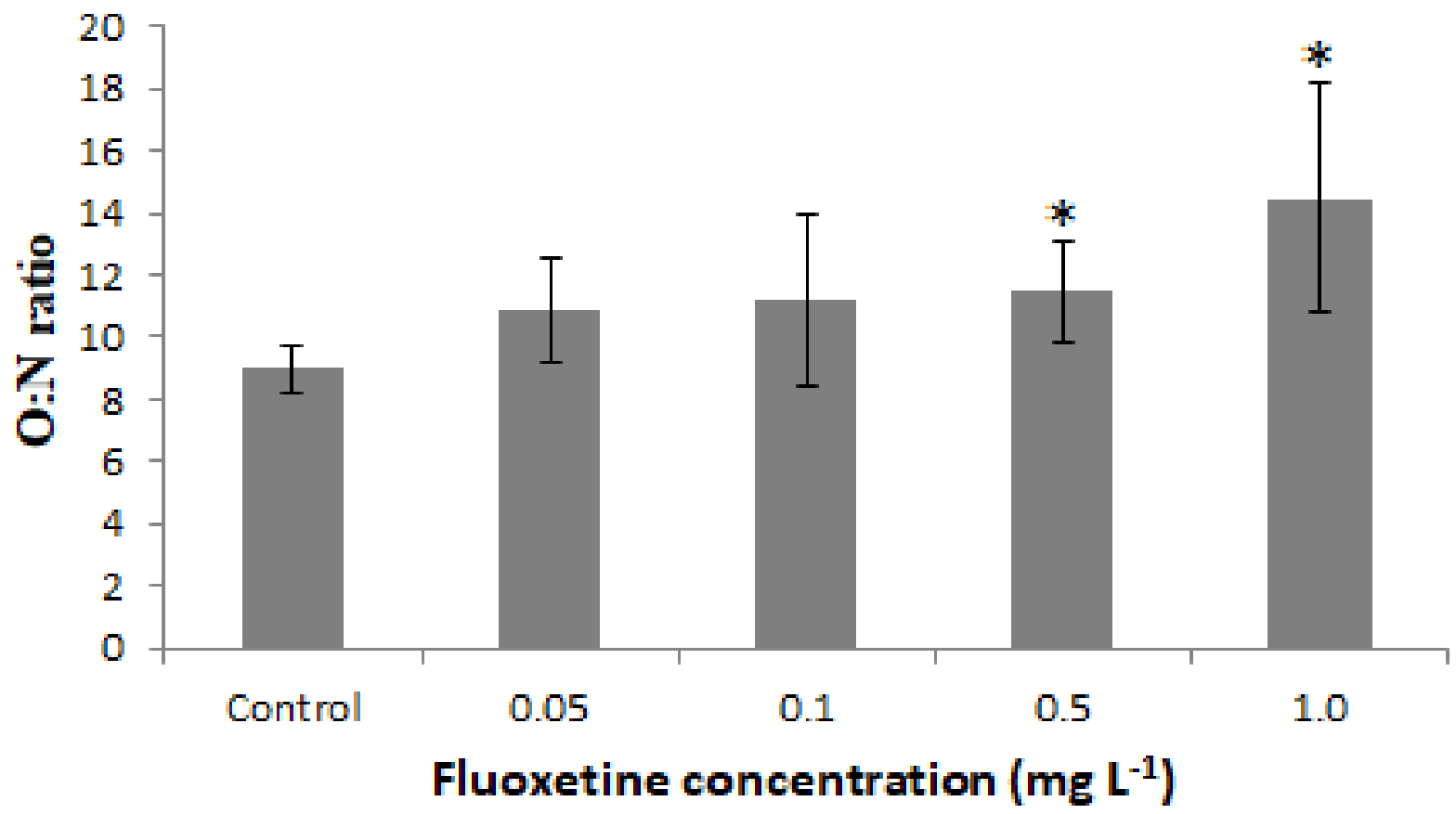

Figure 3. Mean of atomic ratio of oxygen consumed to ammonia nitrogen excreted $(\mathrm{O}: \mathrm{N})$ relative to different fluoxetine concentrations (mgL-1) of Deuterodon iguape. The bars are the respective standard deviations. * Indicates statistical difference compared to the control group.

Assessing the toxicity of fluoxetine in shrimps, it was observed that the 96-hour LC50 values of Palaemon pandaliformis displayed a greater toxicity (Table 1 ). 
Table 1. Percentage mortality (\%) of shrimp exposed to increasing concentrations of Fluoxetine $\left(\mu \mathrm{gL}^{-1}\right)$ for $96 \mathrm{~h}$ and the average lethal dose (CL50 with 95\% confidence limit) calculated by Spearman-Karber analysis.

\begin{tabular}{cccccccc}
\hline $\begin{array}{c}\text { Time of exposure } \\
(\mathrm{h})\end{array}$ & 0 & 5 & 10 & 30 & 60 & 100 & $\begin{array}{c}\text { CL50 } \\
\text { Fluoxetine }\left(\mu \mathrm{L} \mathrm{L}^{-1}\right)\end{array}$ \\
\hline 24 & 0.00 & 0.00 & 0.00 & 6.66 & 100 & 100 & $39.61(35.61-44.86)$ \\
48 & 0.00 & 0.00 & 0.00 & 20 & 100 & 100 & $35.47(29.48-42.68)$ \\
72 & 0.00 & 0.00 & 6.66 & 40 & 100 & 100 & $27.93(21.66-36.02)$ \\
96 & 0.00 & 0.00 & 6.66 & 46.6 & 100 & 100 & $26.31(20.33-34.06)$ \\
\hline
\end{tabular}

Moreover, the metabolic rate increased significantly in the groups exposed to the highest concentrations of fluoxetine (30.0 and $60.0 \mu \mathrm{g} \mathrm{L}-1)$ when compared to the control group (ANOVA; $p<0.05$ ) in Palaemon pandaliformis (Figure 4).

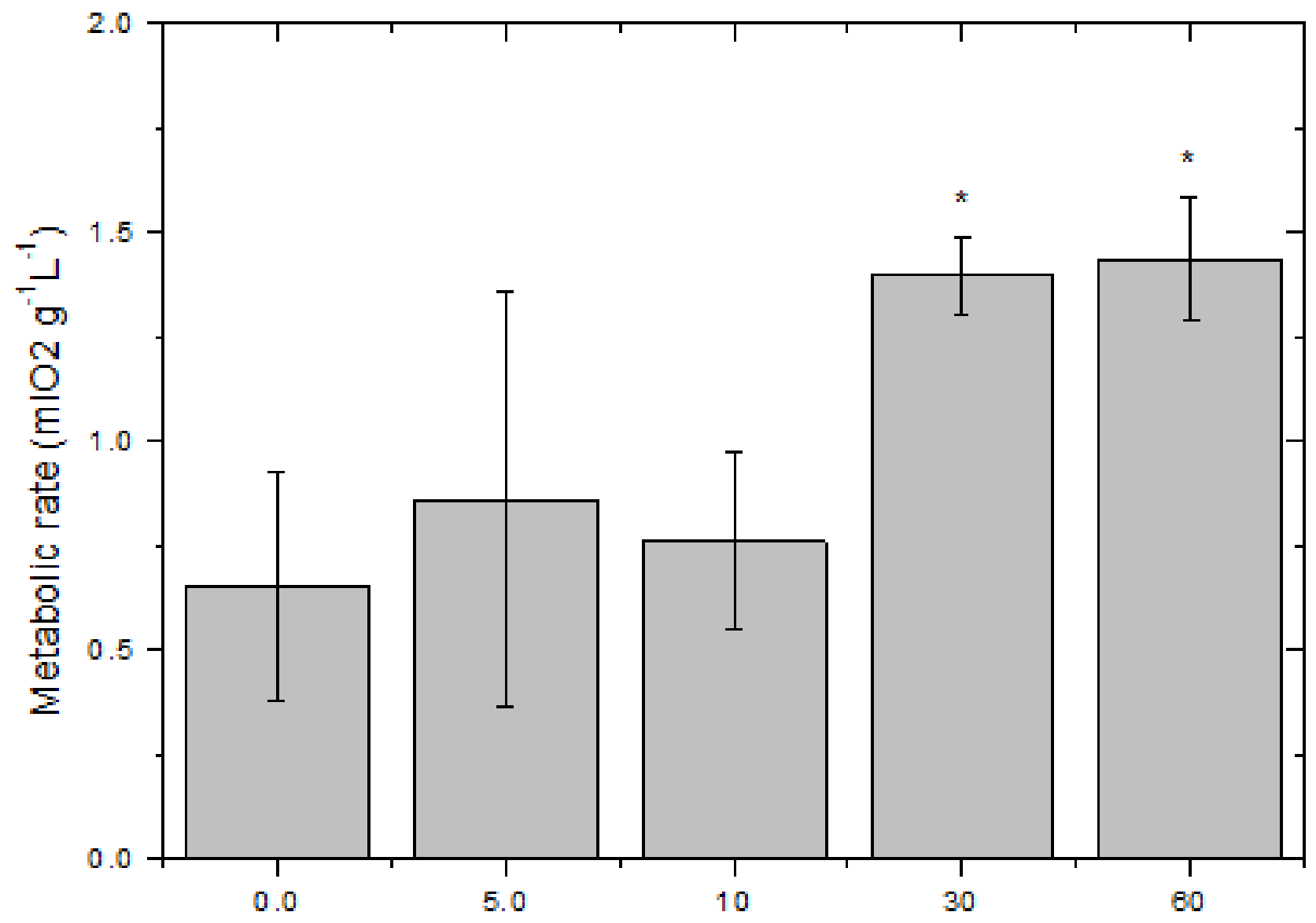

\section{Fluoxetine concentration $\left(\mu \mathrm{L} \mathrm{L}^{-1}\right)$}

Figure 4. Mean of metabolic rate $\left(\mathrm{mLO}_{2} \mathrm{~g}^{-1} \mathrm{~h}^{-1}\right)$ relative to different fluoxetine concentrations $\left(\mu \mathrm{gL}^{-1}\right)$ of Palaemon pandaliformis. The bars are the respective standard deviations. *Indicates statistical difference compared to the control group.

The specific excretion of ammonia in the groups exposed to the highest concentrations of fluoxetine (10.0, 30.0 and $60.0 \mathrm{~g} \mathrm{~L}^{-1}$ ) was statistically higher when compared to the control group (ANOVA; $p<0.05$ ), in Palaemon pandaliformis (Figure 5). 


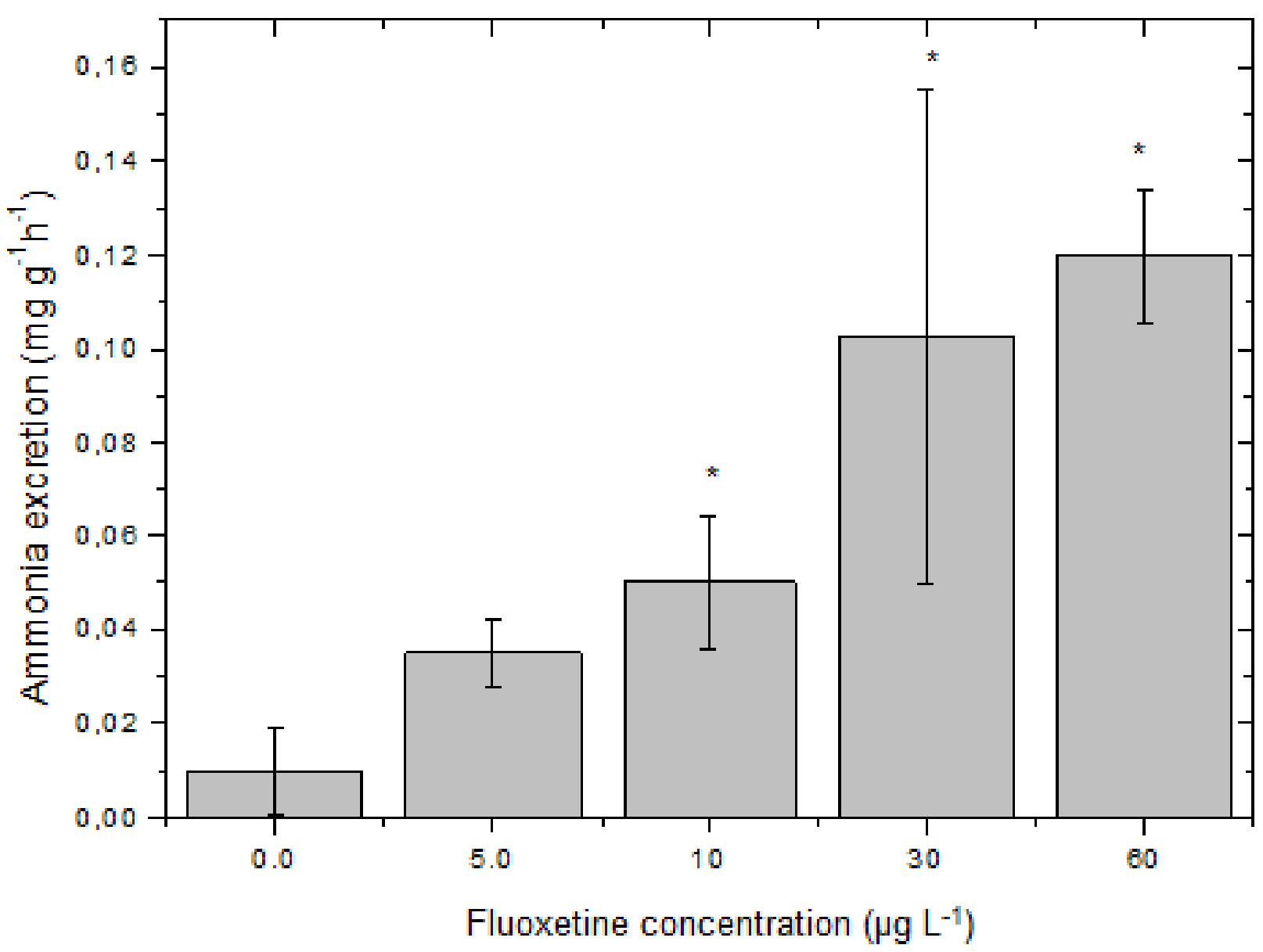

Figure 5. Mean of specific ammonia excretion $\left(\mathrm{mgL}^{-1}\right)$ relative to different fluoxetine concentrations $\left(\mu \mathrm{gL}^{-1}\right)$ of Palaemon pandaliformis. The bars are the respective standard deviations. *Indicates statistical difference compared to the control group.

\section{DISCUSSION}

Aquatic environments are being contaminated by drugs and their correlates, and among them is fluoxetine hydrochloride [57], which was used in the present study. This drug is considered an emerging environmental contaminant, as it is increasingly present in the waters of the world [58] and arouses the attention of sanitation agencies because it has lipophilic characteristics and low biodegradability in the environment [59].

Moreover, knowing that the anatomical organization of brain serotonergic systems is remarkably conserved among vertebrates [60], implying that the functions of the 5- $\mathrm{HT}$ neurotransmitter may also have been conserved as revealed in recent studies with teleosts [61-63], the fish, Deuterodon iguape, was chosen as a biological model, and it is an endemic species of small rivers and coastal streams of the state of São Paulo [64,65]. Apparently, the neurotransmitter 5-HT also plays an important role in aquatic invertebrates, such as crustaceans, mediating many physiological and behavioral processes [66]. Therefore, we used the shrimp, Palaemon pandaliformis, as a biological model for the present study, it is a species native to Brazil. Both species were shown to be sensitive to exposure to the different concentrations of fluoxetine hydrochloride revealed by the increase in routine metabolism (metabolic rate and specific ammonia excretion).

Another serotoninergic process in fish is the excretion of ammonia, which is the main product of fish excretion [67-69], through the gills. This excretion is attributed to urea transport protein (tUT), which is regulated by the hormone cortisol and the $5-\mathrm{HT}$ neurotransmitter [70]. On the one hand, cortisol stimulates $\mathrm{Na}+/ \mathrm{K}+-$ ATPase activity in gills [71], stimulating $\mathrm{Na}^{+}, \mathrm{Cl}^{-}$and $\mathrm{Ca}^{2+}$ absorption [72] and increasing the cell chloride area in the gills resulting in the inhibition of ammonia excretion [73,74]. On the other hand, high concentrations of $5-\mathrm{HT}$ stimulate ammonia excretion [75,76]. The fluoxetine, which blocks the stress response by increasing the action of $5-\mathrm{HT}$, reduces the influx of $\mathrm{Na}^{+}$and $\mathrm{K}^{+}$by increasing ammonia excretion 
[77]. This was corroborated in the present study, where exposure to fluoxetine for 24 hours increased specific ammonia excretion at three concentrations tested $\left(0.05 ; 0.1 ; 0.5 \mathrm{mg} \mathrm{L}^{-1}\right)$ in Deuterodon iguape.

Increased metabolic rate and ammonia excretion may indicate the need for additional energy to maintain homeostasis [78]. Thus, the atomic oxygen: nitrogen ratio $(\mathrm{O}: \mathrm{N})$ is an indicator of metabolic processes using different energy substrates in various environments [56].

The present study revealed that exposure to concentrations of $0.05 ; 0.1 ; 0.5 \mathrm{mg} \mathrm{L}^{-1}$ fluoxetine, in addition to the control group, the O:N ratio was maintained in the range of 3-16 indicating, according to Mayzaud and Conover [56], preferential oxidation of protein substrate, preserving the energy balance of the fish [79]. It is noteworthy that the group exposed to $0.5 \mathrm{mg} \mathrm{L}^{-1}$ of fluoxetine significantly increased protein substrate oxidation for obtaining energy in relation to the control group. This result warns of an increase in energy requirements which is reflected in the results obtained in the group exposed to $1.0 \mathrm{mg} \mathrm{L}^{-1}$ of fluoxetine.

Although the average O:N ratio of the group exposed to $1.0 \mathrm{mg} \mathrm{L}^{-1}$ fluoxetine was 14.46 remaining in the oxidative range preferentially of protein substrate, it is observed in the standard deviation $( \pm 3.69)$ that the $\mathrm{O}: \mathrm{N}$ ratio of some individuals in the group reached the 16-60 range which reveals a mixed oxidation of protein and lipid substrates [56].

Thus, the data on the O:N ratio demonstrated the need for the use of different metabolic substrates as energy sources in a dose-dependent manner during exposure to fluoxetine. These data reinforce the tendency for a decreased metabolic rate and ammonia excretion at higher fluoxetine concentrations ( 0.5 and $\left.1.0 \mathrm{mg} \mathrm{L}^{-1}\right)$. However, it is noteworthy that no individual reached the range of more than 60 , which would represent oxidation of predominant lipid substrate to meet high energy demands [56].

The results of this study confirm that the fluoxetine was toxic to $P$. pandaliformis and $D$. iguape, which are ecologically and economically important shrimp species in the coastal waters of Brazil. The most sensitive specie to fluoxetine was the shrimp. The effects of fluoxetine on crustaceans is not well documented yet, but there is a study for $C$. dubia and D. magna. For example, the 96-hour LC50 of fluoxetine for $C$. dubia was $820 \mu \mathrm{g} \mathrm{L}^{-1}$ and for $D$. magna it was $720 \mu \mathrm{g} \mathrm{L}^{-1}$ [13]. In addition, 96-hour LC50 values of fluoxetine for the fish, $P$. promelas, was $705 \mu \mathrm{g} \mathrm{L}^{-1}$ [13]. In this study, fluoxetine exhibited a greater toxicity on Palaemon in which the 96-hour LC50 values were $26.31 \mathrm{~g} \mathrm{~L}^{-1}$. Brooks and coauthors [13] and Henry and coauthors [29] worked on another crustacean species and found that the mortality of $C$. dubia increases with increasing SSRIs concentration exposure [29].

It is known that serotonin physiologically regulates biological activities, controlling the release of neurohormones from the X-organ/ sinus gland complex [79,80]. This complex, in crustaceans, produces hormones related to reproduction, nutrient metabolism and growth; and the most well-known of these hormones which possesses a quick response is the Crustacean Hyperglycemic Hormone $(\mathrm{CHH})$ [81].

Thus, exposure to fluoxetine maintains the hyperglycemic effect of serotonin resulting in physiological changes that increase metabolic costs in invertebrates. Lange and coauthors [82], analyzing small crustaceans of Gammarus pulex exposed to concentrations of 10-100 $\mathrm{ng} \mathrm{L}^{-1}$ of fluoxetine, observed increased ventilation showing signs of stress. In addition, exposure to fluoxetine also alters the swimming behavior of invertebrates. Castro-Català and coauthors [83] observed an increase in the swimming speed of the small freshwater crustacean, Gammarus pulex, exposed to concentrations of $100 \mathrm{ng} \mathrm{L}^{-1}$ of fluoxetine.

Studies with mussels, Lampsilis fasciola, demonstrated that exposure to fluoxetine (concentration of 22.3 $\mu \mathrm{g} \mathrm{L}^{-1}$ ) increased the distance covered by these animals; however, the authors warn that the movements were more irregular with changes in position behavior and movement time [84].

Nevertheless, an increase in the metabolic rate of Palaemon pandaliformis at the highest concentrations of exposure (30.0 and $60.0 \mathrm{~g} \mathrm{~L} \mathrm{~L}^{-1}$ ) as evidenced in the present study, may be related to the need for meeting the increase in metabolic costs, increasing the rate of glycolysis [85].

Ammonia, the final product of protein catabolism, is responsible for more than half of nitrogenous residues released by decapod crustaceans [86]. Therefore, the results obtained in the present study, where the increase in the specific ammonia excretion was related to the increase in the metabolic rate, can be justified by the prolonged action of serotonin through the influence of fluoxetine, which results in a hyperglycemic effect in which the organism increases the catabolism of one of the most commonly used energy substrates, amino acids, to maintain high glucose levels [87].

In addition, several studies show that different contaminants such as lead [49], nitrite [88], cadmium and zinc [89] can increase the excretion of ammonia in crustaceans reinforcing the thesis that their response is to eliminate the compound from their body more quickly $[49,90]$.

Given the fact that exposure to the highest concentrations of fluoxetine causes an increase in routine metabolism both in vertebrates (Deuterodon iguape) and in invertebrates (Palaemon pandaliformis), in just 
24 hours and 2 hours of exposure, respectively, we warn concerning the ecological risk of this medication in aquatic communities.

Although energy expenditure, as a response to stress, is necessary for the body to balance itself, Ceccarelli and coauthors [91] point out that if the scenario persists, characterizing a situation of chronic exposure, other processes may be compromised such as reproduction, growth and resistance to diseases, which can lead to death [92]. Schultz and coauthors [31], exposing Pimephales promelas fish to a concentration of $28 \mathrm{ng} \mathrm{L}^{-1}$ for 21 days observed impairment in testicular morphology. Upon exposure to a fluoxetine concentration of $69 \mathrm{\mu g} \mathrm{L}^{-1}$, Potamopyrgus antipodarum showed a decrease in reproduction after 42 days [83]. When exposing Oryzias latipes to a concentration of $5 \mathrm{\mu g} \mathrm{L}^{-1}$ of fluoxetine, Foran and coauthors [93] observed an increase in circulating plasma estradiol levels.

In addition to the need for more research on aquatic animals exposed to fluoxetine for acute and chronic periods, Mesquita and coauthors [94] also highlight the importance of studies on toxicological interactions. Nevertheless, the already known changes in the exposure of aquatic organisms to the drug, fluoxetine, concern additional changes in the aquatic communities through both the vertical structure, causing an imbalance in the predator-prey relationship, and also in the horizontal structure, in which the animals compete for the same food resource [95].

Fluoxetine and norfluoxetine hydrochloride act and bioaccumulate in the fish brain as shown in studies with wild fish, in which noted concentrations of these compounds ranged between 1.58 and $8.86 \mathrm{ng} \mathrm{g}^{-1}$ [96]. Thus, this drug enhances the effect of the 5-HT neurotransmitter [5], which is responsible for the neuroendocrine modulation of physiological processes in the brain, leading to concerns about its interference with these processes [97]. In addition, vertebrate brains are metabolically one of the most active organs and are extremely sensitive to energy metabolism disorders [98,99], accounting for $2.7-3.4 \%$ of total body energy consumption in ectothermal vertebrates [100].

It is known also that besides the brain, the liver is also a key organ involved in the regulation of energy metabolism in fish. As in the brain, Brooks and coauthors [96] detected a liver bioconcentration within the range of 1.34 and $10.27 \mathrm{ng} \mathrm{g}^{-1}$ for fluoxetine and norfluoxetine, respectively. Smith and coauthors [101] believe that bioaccumulation is a result of slower metabolism of fluoxetine in the liver in fish compared to mammals.

Thus, the possible action and bioaccumulation of fluoxetine in a Deuterodon iguape's brain and liver results in altered energy metabolism, in which both organs need more energy, not only for a compensatory response caused by stress, but also as a result of decreased oxygen solubility in salt water $[74,102,103]$. Thus, data from the present study demonstrate an increase in metabolic rate at all fluoxetine concentrations tested $\left(0.05,0.1,0.5,1.0 \mathrm{mg} \mathrm{L}^{-1}\right)$ within 24 hours of exposure.

\section{CONCLUSION}

Exposure to fluoxetine hydrochloride increases metabolic rate and specific ammonia excretion of Deuterodon iguape and Palaemon pandaliformis after 24 and 2 hours of exposure, respectively.

The highest concentration of fluoxetine hydrochloride tested $\left(1.0 \mathrm{mg} \mathrm{L}^{-1}\right)$ required of the Deuterodon iguape different energy substrates (protein and lipid) to maintain its homeostasis.

Results show that Deuterodon iguape and Palaemon pandaliformis are good biological models for fluoxetine exposure studies.

Funding: This research was funded by Fundação de Amparo à Pesquisa do Estado de São Paulo (FAPESP), grant number 2018/19747-2 and National Council for Scientific and Technological Development (CNPq, Brazil, for the productivity research grants, grant number 302705/2020-1

Conflicts of Interest: The authors declare no conflict of interest.

\section{REFERENCES}

1. Hiemke C, Härtter S. Pharmacokinetics of selective serotonin reuptake inhibitors. Pharmacol Ther. 2000 Jan;85(1):11-28.

2. Stanley JK, Ramirez AJ, Chambliss CK, Brooks BW. Enantiospecific sublethal effects of the antidepressant fluoxetine to a model aquatic vertebrate and invertebrate. Chemosphere. 2007 Aug;69(1):9-16.

3. Lesch KP, Wolozin BL, Murphy DL, Riederer P. Primary structure of the human platelet serotonin uptake site: identity with the brain serotonin transporter. J Neurochem. 1993 Jun;60(6):2319-22.

4. Rang H, Dale M. Pharmacology. Rio de Janeiro: Elsevier; 2007. 
5. Mennigen JA, Stroud P, Zamora JM, Moon TW, Trudeau VL. Pharmaceuticals as neuroendocrine disruptors: lessons learned from fish on Prozac. J Toxicol Environ Health. 2011 Jul;14(5-7):387-412.

6. Lillesaar C. The serotonergic system in fish. J Chem Neuroanat. 2011 Jul;41(4):294-308.

7. Azmitia EC. Serotonin neurons, neuroplasticity, and homeostasis of neural tissue. Neuropsychopharmacology. 1999 Aug;21(2):33-45.

8. Milea D, Verpillat $P$, Guelfucci F, Toumi M, Lamure M. Prescription patterns of antidepressants: findings from a US claims database. Curr Med Res Opin. 2010 Jun;26(6):1343-53.

9. Winder VL, Pennington PL, Hurd MW, Wirth EF. Fluoxetine effects on sheepshead minnow (Cyprinodon variegatus) locomotor activity. J Environ Sci Health. 2012 Feb;47(1):51-8.

10. Silva LJ, Lino CM, Meisel LM, Pena A. Selective serotonin re-uptake inhibitors (SSRIs) in the aquatic environment: an ecopharmacovigilance approach. Sci Total Environ. 2012 Oct;437(1):185-95.

11. Resende SC, Ferreira TDR, Façanha TMP, Paiva CCS, Silveira AA, Souza APS. The use of antidepressants by students in a higher education institution and the possible pharmaceutical interventions. Braz J Health Rev. 2019 Feb;2(1):1633-49.

12. World Health Organization-WHO. Depression: Let's talk; 2017.

13. Brooks BW, Foran CM, Richards SM, Weston J, Turner PK, Stanley JK, et al. Aquatic ecotoxicology of fluoxetine. Toxicol Lett. 2003 May;142(3):169-83.

14. Brodin T, Fick J, Jonsson M, Klaminder J. Dilute concentrations of a psychiatric drug alter behavior of fish from natural populations. Science. 2013 Feb;339(6121):814-5.

15. Kwon JW, Armbrust KL. Laboratory persistence and fate of fluoxetine in aquatic environments. Environ Toxicol Chem. 2006 Oct;25(10):2561-8.

16. Calisto V, Esteves VI. Psychiatric pharmaceuticals in the environment. Chemosphere. 2009 Nov;77(10):1257-74.

17. Togunde OP, Oakes KD, Servos MR, Pawliszyn J. Determination of pharmaceutical residues in fish bile by solidphase microextraction couple with liquid chromatography-tandem mass spectrometry (LC/MS/MS). Environ Sci Technol. 2012 May;46(10):5302-9.

18. Daughton CG, Ternes TA. Pharmaceuticals and personal care products in the environment: agents of subtle change?. Environ Health Perspect. 1999 Dec;107(6):907-38.

19. Daniel WA, Wöjcikowski J. Contribution of lysosomal trapping to the total tissue uptake of psychotropic drugs. Pharmacol Toxicol. 1997 Feb;80(2):62-8.

20. Halling-Sørensen B, Nors Nielsen S, Lanzky PF, Ingerslev F, Holten Lutzhøft HC, Jørgensen SE. Occurrence, fate, and effects of pharmaceutical substances in the environment- a review. Chemosphere. 1998 Jan;36(2):357-93.

21. Paterson G, Metcalfe CD. Uptake and depuration of the anti-depressant fluoxetine by the Japanese medaka (Oryzias latipes). Chemosphere. 2008 Dec;74(1):125-30.

22. Brooks BW, Chambliss CK, Stanley JK, Ramirez A, Banks KE, Johnson RD, et al. Determination of select antidepressants in fish from an effluent-dominated stream. Environ Toxicol Chem. 2005 Feb;24(2):464-9.

23. Schultz MM, Furlong ET, Kolpin DW, Werner SL, Schoenfuss HL, Barber LB, et al. Antidepressant pharmaceuticals in two US effluent-impacted streams: occurrence and fate in water and sediment, and selective uptake in fish neural tissue. Environ Sci Technol. 2010 Mar;44(6):1918-25.

24. Ramirez AJ, Brain RA, Usenko S, Mottaleb MA, O'Donnell JG, Stahl LL, et al. Occurrence of pharmaceuticals and personal care products in fish: results of a national pilot study in the United States. Environ Toxicol Chem. 2009 Dec;28(12):2587-97.

25. Marshall WS, Grosell M. Ion transport, osmoregulation, and acid-base balance. Physiol Fishes. 2006 Mar;3(1):177230.

26. Barbosa-Junior A, Alves FL, Pereira ASF, Ide LM, Hoffmann A. Behavioral characterization of the alarm reaction and anxiolytic-like effect of acute treatment with fluoxetine in piaucu fish. Physiol Behav. 2012 Feb;105(3):784-90.

27. Park JW, Heah TP, Gouffon JS, Henry TB, Sayler GS. Global gene expression in larval zebrafish (Danio rerio) exposed to selective serotonin reuptake inhibitors (fluoxetine and sertraline) reveals unique expression profiles and potential biomarkers of exposure. Environ Pollut. 2012 Aug;167(1):163-70.

28. Landgraf R. Neuropeptides in Anxiety Modulation. In: Holsboer F, Ströhle A. (eds) Anxiety and Anxiolytic Drugs. Handbook of Experimental Pharmacology. Berlin: Springer; 2005.

29. Henry TB, Black MC. Acute and chronic toxicity of fluoxetine (selective serotonin reuptake inhibitor) in western mosquitofish. Arch Environ Contam Toxicol. 2008 Feb;54(2):325-30.

30. Overli O, Winberg S, Damsgard B, Jobling M. Food intake and spontaneous swimming activity in Arctic char (Salvelinus alpinus): Role of brain serotonergic activity and social interactions. Can J Zool. 1998 Jul;76(7):136670. 
31. Schultz MM, Painter MM, Bartell SE, Logue A, Furlong ET, Werner SL, et al. Selective uptake and biological consequences of environmentally relevant antidepressant pharmaceutical exposures on male fathead minnows. Aquat Toxicol. $2011 \mathrm{Jul} ; 104(1-2): 38-47$.

32. Cericato L, Neto JGM, Kreutz LC, Quevedo RM, Rosa JGS, Koakoski G, et al. Responsiveness of the interrenal tissue of Jundiá (Rhamdia quelen) to an in vivo ACTH test following acute exposure to sublethal concentrations of agrichemicals. Comp Biochem Physiol. 2009 Apr;149(3):363-7.

33. Barton BA. Stress in fishes: a diversity of responses with particular reference to changes in circulating corticosteroids. Integr Comp Biol. 2002 Jul;42(3):517-25.

34. Wong BBM, Candolin U. Behavioral responses to changing environments. Behav Ecol. 2015 May;26(3):665-73.

35. Huber R, Smith K, Delago A, Isakkson K, Kravitz EA. Serotonin and aggressive motivation in crustaceans: altering the decision to retreat. Proc Natl Acad Sci USA. 1997 May;94(11):5939-42.

36. Ram JL, Crawford GW, Walker JU, Mojares JJ, Patel N, Fong PP, et al. Spawning in the zebra mussel (Dreissena polymorpha): activation by internal or external application of serotonin. J Exp Zool. 1993 Apr;265(5):587-98.

37. Brodfuehrer PD, Debski EA, O'Gara BA, Friesen WO. Neuronal control of leech swimming. J Neurobiol. 1995 Jul;27(3):403-18.

38. Santos LH, Araujo AN, Fachini A, Pena A, Delerue-Matos C, Montenegro MCBSM. Ecotoxicological aspects related to the presence of pharmaceuticals in the aquatic environment. J. Hazard Mater. 2010 Mar;175(1-3):45-95.

39. Chu S, Metcalfe CD. Analysis of paroxetine, fluoxetine and norfluoxetine in fish tissues using pressurized liquid extraction, mixed mode solid phase extraction cleanup and liquid chromatography-tandem mass spectrometry. $J$ Chromatogr A. 2007 Sep;1163(1-2):112-8.

40. Fonseca T, Costa-Pierce BA, Valenti WC. Lambari aquaculture as a means for the sustainable development of rural communities in Brazil. Rev Fish Sci Aquacul. 2017 May;25(4):316-30.

41. Silva NJR, Lopes MC, Fernandes JBK, Henriques MB. Caracterização dos sistemas de criação e da cadeia produtiva do lambari no Estado de São Paulo. Inf Econômicas. 2011 Set;41(9):17-28.

42. Henriques MB, Carneiro JS, Fagundes L, Castilho-Barros L, Barbieri E. Economic feasibility for the production of live baits of lambari (Deuterodon iguape) in recirculation system. Bol Instit Pesca. 2019 Dec;45(4):516.

43. Sabbag OJ, Takahashi LS, Silveira AN, Aranha AS. Custos e viabilidade econômica da produção de lambari-dorabo-amarelo em Monte Mastelo/SP: Um estudo de caso. Bol Inst Pesca. 2011 Jul;37(3):307-15.

44. Henriques MB, Fagundes L, Petesse ML, Silva NJR, Rezende KFO, Barbieri E. Lambari fish Deuterodon iguape Eigenmann, 1907 as an alternative to live bait for estuarine recreational fishing. Fish Manag Ecol. 2018 Sep;25(5):400-7.

45. Foster C, Amado EM, Souza MM, Freire CA. Do osmoregulators have lower capacity of muscle water regulation than osmoconformers? A study on decapod crustaceans. J Exp Zool. 2009 Feb;313A(2):80-94.

46. Mortari RC, Negreiros-Fransozo ML. Composition and abundance of the caridean prawn species in two estuaries from the northern coast of São Paulo State, Brazil. Acta Limnologica Brasiliensia. 2007 Feb;19(2):211-9.

47. Ferreira RS, Vieira RRR, D'Incao F. The marine and estuarine shrimps of the Palaemoninae (Crustacea: Decapoda: Caridea) from Brazil. UFRG: Rio Grande; 2010.

48. Fry FEJ. The Effect of Environmental Factors on the Physiology of Fish. In: Hoar WS, Randall DJ (Eds.). Fish Physiology. Academic Press: New York; 1971.

49. Doi AS, Collaço FL, Sturaro LGR, Barbieri E. Efeito do chumbo em nível de oxigênio e amônia no camarão rosa (Farfantepeneaus paulensis) em relação à salinidade. Mundo da Saúde. 2012 Aug;36(4):594-600.

50. Melo CB, Côa F, Alves OL, Martinez DST, Barbieri E. Co-exposure of graphene oxide with trace elements: Effects on acute ecotoxicity and routine metabolism in Palaemon pandaliformis (shrimp). Chemosphere. 2019 May;223(1):157-64.

51. Barbieri E, Ferrarini AMT, Rezende KFO, Martinez DST, Alves OL. Effects of multiwalled carbon nanotubes and carbofuran on metabolism in Astyanax ribeirae, a native species. Fish Physiol Biochem. 2019 Feb;45(1):417-26.

52. Rezende KFO, Bergami E, Alves KVB, Corsi I, Barbieri E. Titanium dioxide nanoparticles alter routine metabolism and cause histopathological alterations in Oreochromis niloticus. Bol Inst Pesca. 2018 Mar;44(2):1-11.

53. Barbieri E. Use of metabolism and swimming activity to evaluate the sublethal toxicity of surfactant (LAS-C12) on Mugil platanus. Braz Arch Biol Technol. 2007 Jan, 50(1):191-112

54. Xia JG, Nie LJ, Mi XM, Wang WZ, Ma YJ, Cao ZD, et al. Behavior, metabolism and swimming physiology in juvenile Spinibarbus sinensis exposed to PFOS under different temperatures. Fish Physiol Biochem. 2015 Oct;41(5):1293304.

55. Gaigher NLF, Duarte L, Arfux C. Commerce of for antidepressants compounding pharmacies. Interbio. 2013 Feb;7(1):16-25.

56. Mayzaud P, Conover RJ. O:N atomic ratio as a tool to describe zooplankton metabolism. Marine Ecology Progress Series: Oldendorf. 1988 Jun;45(1):289-302. 
57. Borrely SL. Contaminação das águas por resíduos de medicamentos: ênfase ao cloridrato de fluoxetina. Mundo da Saúde. 2012 Oct;36(4):556-63.

58. McEachran AD, Shea D, Nichols EG. Pharmaceuticals in a temperate forest-water reuse system. Sci Total Environ. 2017 Mar;581(1):705-14.

59. Christensen FM. Pharmaceuticals in the environment: A human risk?. Regul Toxicol Pharmacol. 1998 Dec;28(3):212-21.

60. Parent A, Poitras D, Dube L. Comparative anatomy of central monoaminergic systems. In: Bjorklund A, Hokfelt T (eds.). Handbook of Chemical Neuroanatomy. Amsterdam: Elsevier; 1984.

61. Chen H, Zeng X, Mu L, Hou L, Yang B, Zhao J, et al. Effects of acute and chronic exposures of fluoxetine on the Chinese fish, topmouth gudgeon Pseudorasbora parva. Ecotoxicol Environ Saf. 2018 May;160(1):104-13.

62. Fursdon JB, Martin JM, Bertram MG, Lehtonen TK, Wong BB. The pharmaceutical pollutant fluoxetine alters reproductive behaviour in a fish independent of predation risk. Sci Total Environ. 2019 Feb;650(1):642-52.

63. Martin JM, Bertram MG, Saaristo M, Ecker TE, Hannington SL, Tanner JL, et al. Impact of the widespread pharmaceutical pollutant fluoxetine on behaviour and sperm traits in a freshwater fish. Sci Total Environ. 2019 Feb;650(2):1771-8.

64. Oyakawa OT, Akama A, Mautari KC, Nolasco JC. Peixes de riachos da Mata Atlântica nas unidades de conservação do Vale do Rio Ribeira de Iguape no Estado de São Paulo. São Paulo: Ed. Neotrópica; 2006.

65. Valladão GMR, Gallani SU, Pilarski F. South America fish for continental aquaculture. Rev Aquacul. 2016 Jun;10(2):351-69.

66. Fingerman M. Roles of neurotransmitters in regulating reproductive hormone release and gonadal maturation in decapod crustacean. Invert Repr Dev. 1997 Aug;31(1-3):47-54.

67. Westers H. Fish hatchery management. 2nd ed. Bethesda: American Fisheries Society; 2001.

68. Damato M, Barbieri E. Study on the acute toxicity and metabolic changes caused by cadmium exposure on the fish Hyphessobrycon callistus used as an indicator of environmental health. Mundo da Saúde. 2012 Oct;36(4):574-81.

69. Barbieri E, Rezende KFO, Carneiro JS, Henriques MB. Metabolic and histological alterations after exposing Deuterodon iguape to different salinities. Bol Inst Pesca. 2019 Mar;45(2):1-11.

70. Walsh PJ, Heitz MJ, Campbell CE, Cooper GJ, Medina M, Wang YS, et al. Molecular characterization of a urea transporter in the gill of the gulf toadfish (Opsanus beta). J Exp Biol. 2000 Aug;203(15):2357-64.

71. Dang Z, Balm PH, Flik G, Wendelaar Bonga SE, Lock RA. Cortisol increases $\mathrm{Na}^{+} / \mathrm{K}^{+}-\mathrm{ATPase}$ density in plasma membranes of gill chloride cells in the freshwater tilápia Oreochromis mossambicus. J Exp Biol. 2000 Aug;203(15):2349-55.

72. Kumai Y, Nesan D, Vijayan MM, Perry SF. Cortisol regulates $\mathrm{Na}^{+}$uptake in zebra fish, Danio rerio, larvae via the glucocorticoid receptor. Mol Cell Endocrinol. 2012 Nov;364(1-2):113-25.

73. Wood CM, Warne JM, Wang Y, McDonald MD, Balment RJ, Laurent P, et al. Do circulating plasma AVT and/or cortisol levels control pulsatile urea excretion in the gulf toadfish (Opsanus beta)?. Comp Biochem Physiol. 2001 Jul;129(4):859-72.

74. McDonald MD, Vulesevic B, Perry SF, Walsh PJ. Urea transporter and glutamine synthetase regulation and localization in gulf toadfish gill. J Exp Biol 2009 Mar;212(5):704-12.

75. Wood CM, McDonald MD, Sundin L, Laurent $P$, Walsh PJ. Pulsatile urea excretion in the gulf toadfish: mechanisms and controls. Comp Biochem Physiol. 2003 Dec;136(4):667-84.

76. McDonald MD, Walsh PJ. 5-HT2A-like receptors are involved in triggering pulsatile urea excretion in the gulf toadfish Opsanus beta. J Exp Biol. 2004 May;207(12):2003-20.

77. Abreu MS, Giacomini ACV, Koakoski G, Oliveira TA, Gusso D, Baldisserotto B, et al. Effects of waterborne fluoxetine on stress response and osmoregulation in zebrafish. Environ Toxicol Pharmacol. 2015 Nov;40(3):704-7.

78. Barbieri E, Paes ET. The use of oxygen consumption and ammonium excretion to evaluate the toxicity of cadmium on Farfantepenaeus paulensis with respect to salinity. Chemosphere. 2011 Jun;84(1):9-16.

79. Martin G. Action de la sérotonine sur la glycémie et sur la libération des neurosécrétions contenues dans la glande du sinus de Porcellio dilatatus brandt (Crustacé, Isopode, Oniscoide). C R Soc Biol Ses Filial. 1978 Jul;172(2):3049.

80. Garcia U, Arechiga H. Regulation of crustacean neurosecretory cell activity. Cell Mol Neurobiol. 1998 Feb;18(1):8199.

81. Santos EA, Keller R. Regulation of circulating levels of the crustacean hyperglycemic hormone - evidence of a dual feedback control system. J Comp Physiol. 1993 Oct;163(1):374-9.

82. Lange HJ, Peeters ET, Lürling MFLLW. Changes in ventilation and locomotion of Gammarus pulex (Crustacea, Amphipoda) in response to low concentrations of pharmaceuticals. Hum Ecol Risk Assess. 2009 Feb;15(1):11120. 
83. Castro-Català N, Muñoz I, Riera JL, Ford AT. Evidence of low dose effects on the antidepressant fluoxetine and the fungicide prochloraz on the behaviour of the keystone freshwater invertebrate Gammarus pulex. Environ Pollut. 2017 Dec;231(1):406-14.

84. Hazelton PD, Du B, Haddad SP, Fritts AK, Chambliss CK, Brooks BW, et al. Chronic fluoxetine exposure alters movement and burrowing in adult freshwater mussels. Aquat Toxicol. 2014 Jun;151(1):27-35.

85. Chandurvelan R, Marsden ID, Gaw S, Glover CN. Acute and sub-chronic effects of sub-lethal cadmium exposure on energy metabolism in the freshwater shrimp, Paratya curvirostris. Ecotoxicol Environ Saf. 2017 Jan;135(1):607.

86. Regnault M. Nitrogen excretion in marine and freshwater crustacea. Biol Rev. 1987 Feb;62(1):1-24.

87. Rosas C, Martinez E, Gaxiola G, Brito R, Sanchez A, Soto LA. The effect of dissolved oxygen and salinity on oxygen consumption, ammonia excretion and osmotic pressure of Penaeus setiferus (Linnaeus) juveniles. J Exp Mar Biol Ecol. 1999 Feb;234(1):41-57.

88. Chen JC, Cheng SY. Hemolymph oxygen content, oxyhemocyanin, protein levels and ammonia excretion in the shrimp Penaeus monodon exposed to ambient nitrite. J Comp Physiol B. 1995 Jan;164(1):530-5.

89. Barbieri E, Doi SA. Acute toxicity of ammonia on juvenile cobia (Rachycentron canadum, Linnaeus, 1766) according to the salinity. Aquatic Int. 2012 Aug;20(2):373-82.

90. Moraes BCR, Pfeiffer CW, Guimarães JR, Borges ALN, Campos AN. Efeito de sedimentos contaminados sobre a excreção de nitrogênio do camarão Penaeus paulensis. Braz Arch Biol Technol. 1999 Apr;42(4):1-7.

91. Ceccarelli PS, Senhorini JA, Volpato G. Dicas em Piscicultura. Botucatu: Santana; 2000.

92. Lima LC, Ribeiro LP, Leite RC, Melo DC. Estresse em peixes. Rev Bras Reprod Anim. 2006 Sep;30(3-4):113-7.

93. Foran CM, Weston J, Slattery M, Brooks BW, Huggett DB. Reproductive assessment of Japanese medaka (Oryzias latipes) following a four-week fluoxetine (SSRI) exposure. Arch Environ Contam Toxicol. 2004 May;46(4):511-7.

94. Mesquita SR, Guilhermino L, Guimarães L. Biochemical and locomotor responses of Carcinus maenas exposed to the serotonin reuptake inhibitor fluoxetine. Chemosphere. 2011 Oct;85(6):967-76.

95. Hedgespeth ML, Nilsson PA, Berglund O. Ecological implications of altered fish foraging after exposure to an antidepressant pharmaceutical. Aquat Toxicol. 2014 Jun;151(1):84-7.

96. Brooks BW, Huggett DB, Boxall AB. Pharmaceuticals and personal care products: research needs for the next decade. Environ Toxicol Chem. 2009 Dec;28(12):2469-72.

97. Kreke N, Dietrich DR. Physiological endpoints for potential SSRI interactions in fish. Crit Rev Toxicol. 2008 Oct;38(3):215-47.

98. Sokoloff L. Circulation and energy metabolism of the brain. In: Siegel GJ (ed.). Basic Neurochemistry: Molecular, Cellular, and Medical Aspects. New York: Raven Press; 1989.

99. Magistretti PJ. Brain energy metabolism. In: Zigmond MJ, Bloom FE, Landis SC, Roberts JL, Squire LR (eds.). Fundamental Neuroscience. San Diego: Academic Press; 1999.

100. Van Ginneken V, Nieveen M, Van Eersel R, Van den Thillart G, Addink A. Neurotransmitter levels and energy status in brain of fish species with and without the survival strategy of metabolic depression. Comp Biochem Physiol. 1996 Jun;114(2):189-96.

101. Smith EM, Chu S, Paterson GM, Metcalfe CD, Wilson JY. Cross-species comparison of FLX metabolism with fish liver microsomes. Chemosphere. 2009 Mar;79(1):26-32.

102. Christensen JB, Jensen DL, Grøn C, Filip Z, Christensen TH. Characterization of the dissolved organic carbon in landfill leachatepolluted groundwater. Water Res. 1998 Apr;32(1):125-35.

103. Barbieri E, Branco JO, Ferrão MC, Hidalgo KR. Effects of cadimium and zinc on oxygen consumption and ammonia excretion of the sea-bob shrimp, according to temperature. Bol Inst Pesca. 2013 Feb;39(3):299-309. 